IFAS Extension

\title{
Cypress looper Anacamptodes pergracilis (Hulst) (Insecta: Lepidoptera: Geometridae) ${ }^{1}$
}

Wayne N. Dixon ${ }^{2}$

\section{Introduction}

Anacamptodes pergracilis (Hulst), commonly known as the cypress looper, drew considerable attention in late summer of 1980 with the unexpected defoliation of nearly 28,000 ha of cypress trees in USFS-NPS Big Cypress National Preserve (Collier and Monroe counties). Currently, cypress looper populations are at low levels, even in the Fisheating Creek (Glades County) area, a perennial generator of significant cypress looper defoliation over the past 20 years.

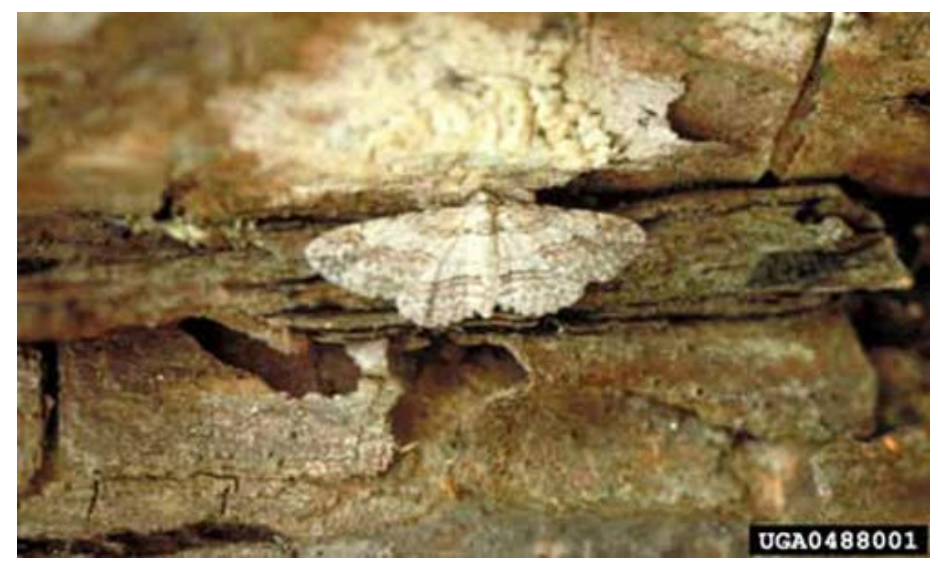

\section{Distribution}

The cypress looper has been recorded from Florida, Georgia, Louisiana, Maryland, Texas, and Virginia and likely occurs throughout the range of its host plants, an area of nearly 2 million ha (Rindge 1966, Williston et al. 1980). In Florida, it has been reported from the following counties: Charlotte, Collier, Dade, Escambia, Glades, Hendry, Lee, Martin, Monroe, Orange, and Palm Beach (Kimball 1965)

\section{Description}

Adult moth is white to grayish white with a body length of 6 to $10 \mathrm{~mm}$ and a wingspan of 22 to $36 \mathrm{~mm}$. Forewings of both sexes are grayish white with blackish brown cross lines and interspersed brown scales. Egg is small, bright green in color, and spherical to keg-shaped. Young larva is uniformly green, similar to foliage color; mature larva is mottled gray-brown- black, closely resembling a twig in coloration and shape. Late instar larva is approximately $25 \mathrm{~mm}$ long (Carothers and Ghent 1980, Rindge 1966).

Figure 1. Adult cypress looper, Anacamptodes pergracilis (Hulst). Credits: John H. Ghent, USDA Forest Service, www.Forestryimages. org.

1. This document is EENY 303, one of a series of the Entomology and Nematology Department, Florida Cooperative Extension Service, Institute of Food and Agricultural Sciences, University of Florida. Original publication date July 2003. Reviewed April 2013. Visit the EDIS website at http://edis.ifas.ufl. edu.

2. Wayne N. Dixon, Florida Department of Agriculture and Consumer Services, Division of Plant Industry, Gainesville, FL, and affiliate faculty, Entomology and Nematology Department, Institute of Food and Agricultural Sciences, University of Florida, Gainesville, FL 32611..

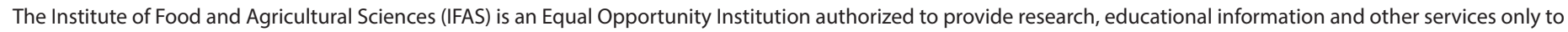

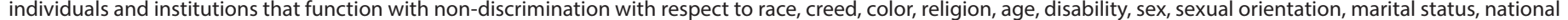
origin, political opinions or affiliations. U.S. Department of Agriculture, Cooperative Extension Service, University of Florida, IFAS, Florida A\&M University Cooperative Extension Program, and Boards of County Commissioners Cooperating. Nick T. Place, Dean 


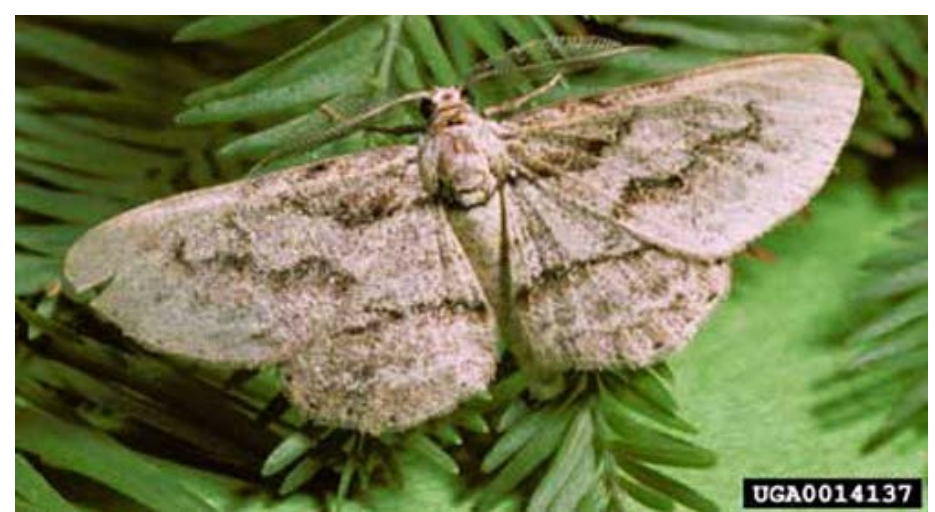

Figure 2. Adult cypress looper, Anacamptodes pergracilis (Hulst). Credits: Gerald J. Lenhard, Louisiana State University, www. Forestryimages.org.

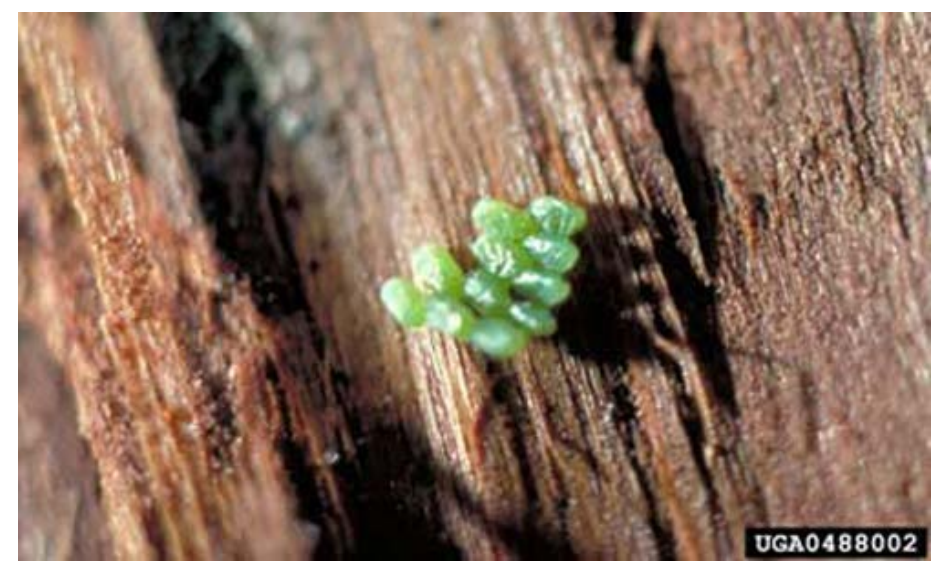

Figure 3. Eggs of the cypress looper, Anacamptodes pergracilis (Hulst). Credits: John H. Ghent, USDA Forest Service, www.Forestryimages. org.

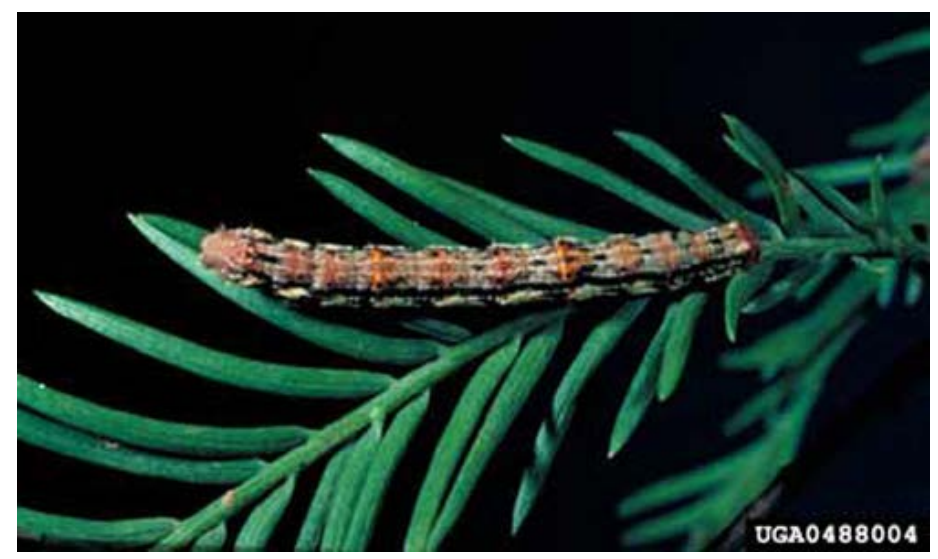

Figure 4. Mature larva of the cypress looper, Anacamptodes pergracilis (Hulst). Credits: John H. Ghent, USDA Forest Service, www. Forestryimages.org.

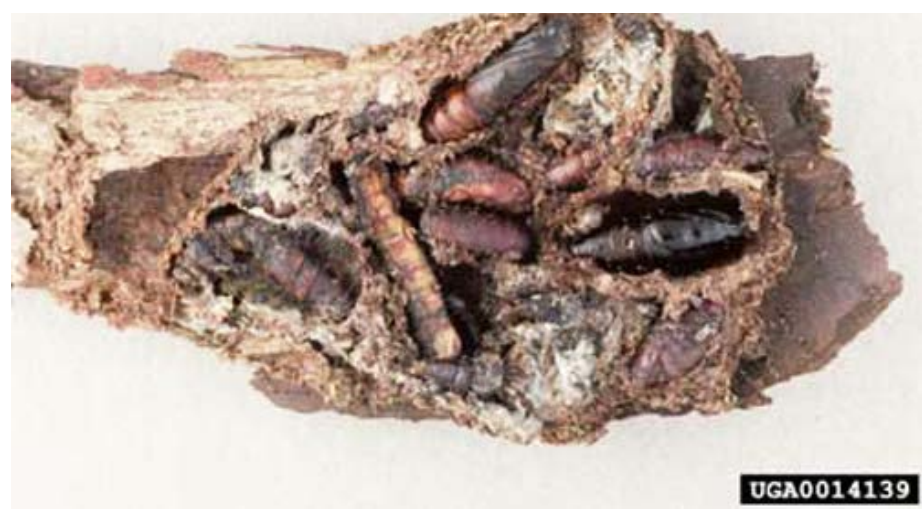

Figure 5. Pupae of the cypress looper, Anacamptodes pergracilis (Hulst). Credits: Gerald J. Lenhard, Louisiana State University, www. Forestryimages.org.

\section{Biology}

In southern Florida, adult moths are present year-round. Female moths deposit small clusters of eggs in bark crevices or under bark flaps. Eggs hatch in nine to12 days. Larvae consume parts of or entire leaves. Approximately three weeks are required for larval development. Prior to pupation, last instar larvae chew shallow depressions into the bark and form a cocoon of silk webbing and bark fibers. Pupation occurs on tree stems and branches and not in the soil as an apparent behavioral adaptation to usual presence of standing water. Adult moths emerge during the night approximately seven to 13 days after the onset of pupation. In general, a complete life cycle requires 1 to $11 / 2$ months (Carothers and Ghent 1980, Kimball 1965, Wilkening 1980).

\section{Hosts}

Baldcypress, Taxodium distichum (L.) Rich., and pondcypress, Taxodium distichum var. nutans (Ait.), are the host plants.

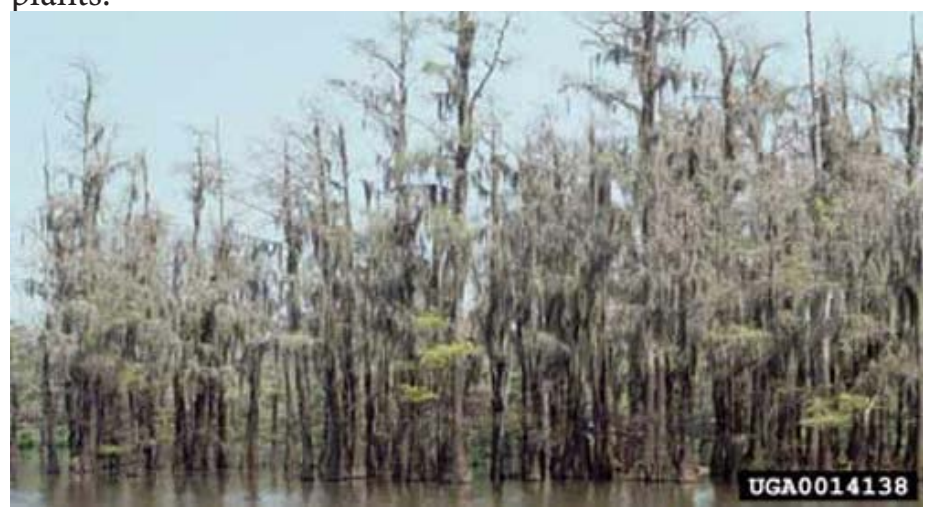

Figure 6. Damage caused by the larvae of the cypress looper, Anacamptodes pergracilis (Hulst).

Credits: Gerald J. Lenhard, Louisiana State University, www. Forestryimages.org. 


\section{Survey and Detection}

Reddening and/or defoliated tree crowns usually become evident by July or August. A close examination of branches with red foliage will reveal partially consumed needles - the red color, a result of leaf desiccation. Early instar larvae blend in well with foliage due to matching colors; late instar larvae, when immobile, closely resemble lichen-covered twigs and shoots. Adult moths are attracted to standard blacklight field traps during nocturnal hours; heaviest catches occur after 2200 hours. Severely defoliated trees will refoliate within weeks after looper feeding; however, branch dieback will be present. In the Big Cypress outbreak, some trees were defoliated three times and $1.5 \mathrm{~m}$ of dieback were observed in the spring of 1981. The leaves of the last crop were smaller and yellowish.

\section{Management}

The environmental hazards of an insecticide preclude use in a cypress strand, which is the typical habitat of the cypress looper. A biological insecticide deserves consideration, e.g. Bacillus thuringiensis Berliner as the active ingredient; however, no efficacy data is available. Natural enemies may play an important regulatory role in cypress looper populations. Intensive sampling of the Big Cypress outbreak revealed most overwintering pupae were parasitized; predominant parasites were Ichneumon navus Say (Hymenoptera: Ichnuemonidae) and Syntomosphyrum clisiocampae (Ashm.) (Hymenoptera: Eulophidae). Tree swallows, warblers, and insect predators (Hemiptera: Reduviidae) were also observed preying on cypress looper caterpillars during the summer months.

\section{Selected References}

Carothers WA, Ghent J. 1980. Biological evaluation of the cypress looper outbreak in the Big Cypress National Preserve in Florida. USFS-S\&PF, SE Area, Atlanta, Georgia. Report 81-1-14. 17 p.

Kimball CP. 1965. Lepidoptera of Florida. Florida Department of Agriculture, Division of Plant Industry, Arthropods of Florida and Neighboring Land Areas 1: 1-363.

Rindge FH. 1966. A revision of the moth genus Anacamptodes (Lepidoptera: Geometridae). Bulletin of the American Museum Natural History 132: 178-243.

Wilkening A. 1980. Report on Anacamptodes rearing project. University of Florida, Department of Entomology and Nematology, Gainesville, Florida. 12 p. (unpublished).
Williston HL, Shropshire FW, Balmer WE. 1980. Cypress management: a forgotten opportunity. USFS-S\&PF, SE Area, Atlanta, Georgia. Forestry Report SA-FR8. 8 p. 